\title{
The basal siliciclastic Silurian-Devonian Tacaratu formation of the Jatobá basin: Analysis of facies, provenance and palaeocurrents
}

\author{
Rizelda Regadas de Carvalho ${ }^{\mathrm{a}}$, Virgínio Henrique Neumann ${ }^{\mathrm{b}, *}$, Gelson Luis Fambrini ${ }^{\mathrm{b}}$, \\ Mário Luis Assine ${ }^{\mathrm{c}}$, Marcela Marques Vieira ${ }^{\mathrm{d}}$, Dunaldson Eliézer Guedes Alcoforado da Rocha ${ }^{\mathrm{e}}$, \\ Germano Mário Silva Ramos ${ }^{\mathrm{b}}$
}

a Instituto Agronômico de Pernambuco, IPA, Brazil

${ }^{\mathrm{b}}$ Departamento de Geologia, DGEO-UFPE, Brazil

c Departamento de Geologia Aplicada, UNESP (Rio Claro), Brazil

d Departamento de Geologia, DGEO-UFRN, Brazil

e CPRM-Serviço Geológico do Brasil, Brazil

\section{A R T I C L E I N F O}

\section{Keywords:}

Tacaratu formation

Sandstone provenance

Palaeocurrents

Diagenesis

\begin{abstract}
A B S T R A C T
The Silurian-Devonian Tacaratu Formation represents the basal siliciclastic sequence of the Jatobá Basin and is the focus of this study. Provenance and palaeocurrent studies are fundamental to the analysis and understanding of the surface diagenetic evolution and tectonic evolution of sedimentary basins. Field work (stratigraphic logs and sedimentary structures) and laboratory studies (petrography) were used for characterization this sedimentary fill. The Tacaratu Formation is comprised of sandstones varying from medium-to coarse-grained with conglomeratic levels. Seven main lithofacies have been identified and described: poorly stratified, matrix to clast-supported conglomerates; trough cross-stratified conglomerates; cross-stratified clast-supported conglomerates; cross-stratified pebbly sandstones; coarse-to medium-grained sandstones with trough cross-stratification; coarse-to medium-grained sandstones with planar cross-stratification; and horizontally stratified sandstones. The compositional analysis of 20 sandstone samples revealed homogeneity and compositional regularity among the samples. Fifty per cent of the sedimentary rocks were classified as quartz arenite, $40 \%$ as sub-litharenite, and $10 \%$ as subarkose. The provenance of these sandstones indicates a stable craton origin, with tectonic events at the margin of the basin. Diagenesis has evolved from eodiagenesis through mesodiagenesis to telodiagenesis. Palaeocurrent readings show a consistent trend to the NNW and a secondary mode to the NE. Palaeocurrent readings point to the São Francisco Craton as the main source area - more precisely the resistant areas of the Borborema Province.
\end{abstract}

\section{Introduction}

In general, the Early Palaeozoic deposits in Brazil are less studied and thus less understood than Mesozoic Strata. However, they constitute the base of several Brazilian basins, notably among the interior basins of north-eastern Brazil (e.g., Araripe, São José do Belmonte, Mirandiba, Cedro, Betânia, Fátima, Tupanaci and Bom Nome) as well as the Tucano Norte and Parnaíba basins (Braun, 1966; Barreto, 1968; Ghignone, 1972; Caputo and Crowell, 1985; Ponte and Appi, 1990; Assine, 1992, 1994, 2007; Mabesoone, 1994; Caixeta et al., 1994; Cesero and Ponte, 1997; Costa et al., 2007; Magnavita et al., 2003; Fambrini et al., 2013; Guzmán-González et al., 2015).
This basal interval constitutes the Tacaratu Formation in the Jatobá Basin. This barren unit involves alluvial conglomerates and very coarseto medium-grained, well stratified sandstones. Hence, it includes rocks appropriate for provenance and palaeocurrent studies.

The Jatobá basin constitutes the northern branch of the RecôncavoTucano-Jatobá Rift System. It has a semi-graben geometry, with a northern faulted margin and a southern flexural margin (Santos et al., 1990; Magnavita et al., 2003). The medium-to coarse-grained sandstones with conglomeratic intervals that outcrop in the northern and southern edges of the Jatobá basin constitute the Tacaratu Formation (Ghignone, 1979; Menezes Filho et al., 1988).

On the southern margin of the basin, the Tacaratu Formation

\footnotetext{
* Corresponding author.

E-mail addresses: rizelda.regadas@gmail.com (R.R.d. Carvalho), neumann@ufpe.br (V.H. Neumann), gelson.fambrini@ufpe.br (G.L. Fambrini),

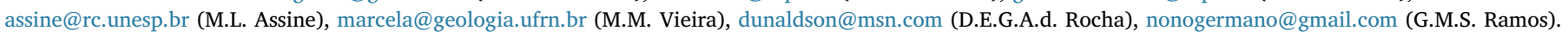




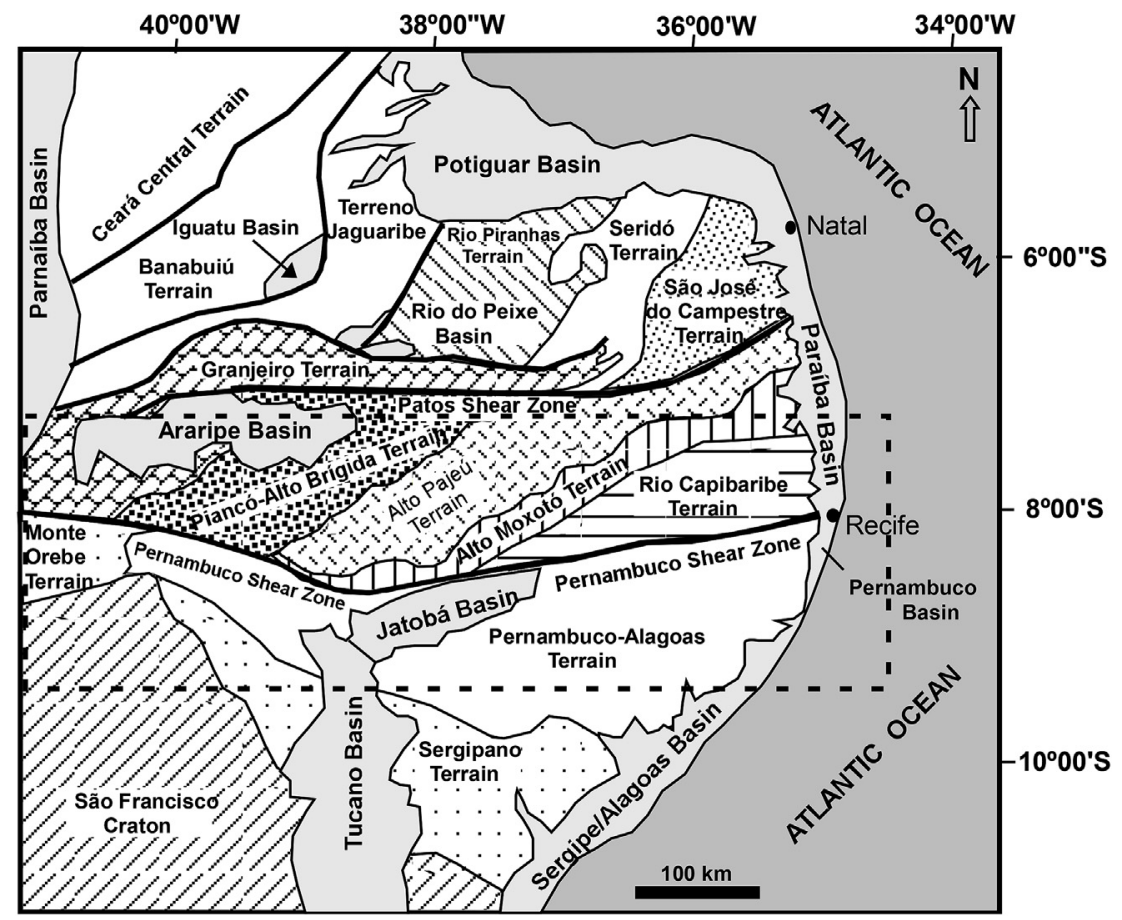

Fig. 1. Geological sketch of the Northeastern region of Brazil (Borborema Province) and its main units. The dashed rectangle represents the area of Fig. 2. Modified from Brito Neves et al. (2000).

outcrops as cuestas, with asymmetric relief resulting from the erosive retreat of some layers of the formation. Scarp fronts (frontslopes) are situated to face southeast, and backslopes have a gently dip to northwest, towards the Jatobá Basin Depocentre (Neumann, 2017).

Provenance and palaeocurrent studies are fundamental for the analysis and understanding of the surface diagenetic evolution and tectonic evolution of sedimentary basins and may significantly contribute to global tectonic reconstructions (Dickinson, 1988; Miall, 2000). When associated with depositional systems, facies and petrographic, such techniques enable the characterization of the source areas that provided debris to the basin. In this context, this article aims to provide information on the facies and depositional systems, provenance and alluvial transport recorded in the Tacaratu Formation to substantiate the understanding of the origin and Early Palaeozoic evolution of the much larger Parnaiba Basin.

\subsection{Geological setting}

Based on Brito Neves et al. (2000), the Jatobá basin is situated between the Transversal and the Meridional Zones (Fig. 1) of the Borborema Province (Brito Neves, 1995; Gomes, 2001). The Transversal Zone includes the Alto Moxotó and Rio Capibaribe terrains, whereas the Meridional Zone comprises the Pernambuco-Alagoas terrain. Unlike the continental margin basins, which evolved from rift to passive margin stages, the Lower Cretaceous Recôncavo, Tucano and Jatobá basins (Fig. 1) are an aborted branch of the South-Atlantic Rift that was abandoned in the Lower Cretaceous (Aragão and Peraro, 1994; Magnavita et al., 2003; Costa et al., 2003, 2007).

The ENE-WSW Jatobá basin is located in the central part of the Pernambuco State and occupies an area of nearly $5000 \mathrm{~km}^{2}$ (Fig. 2). The São Francisco (west) and Ibimirim faults (north) are the main structural boundaries of the Jatobá Basin (Costa et al., 2003, 2007). The altitude usually ranges from 200 to $750 \mathrm{~m}$, although higher altitudes, generally above $900 \mathrm{~m}$, occur in the northern and southern areas of the basin.

The Jatobá Basin includes Palaeozoic (Tacaratu and Inajá formations) and Mesozoic (Aliança, Sergi, Candeias, São Sebastião, Marizal,
Crato, Romualdo and Exú formations and Ilhas Group) lithostratigraphic units (Fig. 3).

Derby (in: Brasil, 1984) defined the Tacaratu Formation as the sandstones exposed in the Tacaratu Hills. Moraes Rego (1936) extrapolated that concept to the entire Jatobá Basin, although it was only later that the unit was formally proposed (Braun, 1966). The later correlated the Silurian-Devonian Tacaratu Formation to both the Serra Grande Group of the Parnaíba Basin and the Cariri Formation of the Araripe Basin.

The Tacaratu Formation continuously outcrops along the eastern and southern borders of the Jatobá Basin, from the southernmost city of Tacaratu to the extreme NE of the study area near the locality of Arcoverde (Fig. 4). This sandstone-rich unit comprises coarse-grained to conglomeratic sandstones and subordinate, usually kaolinite-rich argillite (Rocha and Leite, 1999).

Rocha and Leite (1999) and Rocha and Amaral (2007) associated the Tacaratu Formation with braided streams and related alluvial fans deposits. These proximal facies are supposed to have evolved into flood plain and succeeding eolian strata related to the medial and distal reaches of the depositional system. Mabesoone $(1977,1994)$ suggested that this unit includes both alluvial and coastal facies. A Silurian age for the Tacaratu Formation (Barbosa, 1964) was later extended to the Devonian by Ghignone (1979) based on palynological data (Regali, 1964).

The boundary of the Tacaratu Formation with the underlying crystalline basement is either tectonic (extensional faults) or a nonconformity, whereas its upper contact with the Inajá Formation is gradual (Rocha and Amaral, 2007).

The structural evolution of the Jatobá basin was controlled by the Neoproterozoic Pernambuco Shear Zone. This shear zone, which was reactivated during the Mesozoic Era as the Congo and Ibimirim faults along the N-NW boundary of the basin, controls the depocentre of the Jatobá Basin (Magnavita and Cupertino, 1987; Magnavita, 1994). The Jatobá Basin displays a half graben geometry, where the substrate is composed of tilted blocks that are progressively deeper to the northwest. A slip tectonic model has been proposed for the origin and evolution of this basin. 


\section{SEDIMENTARY BASINS OF PERNAMBUCO STATE}

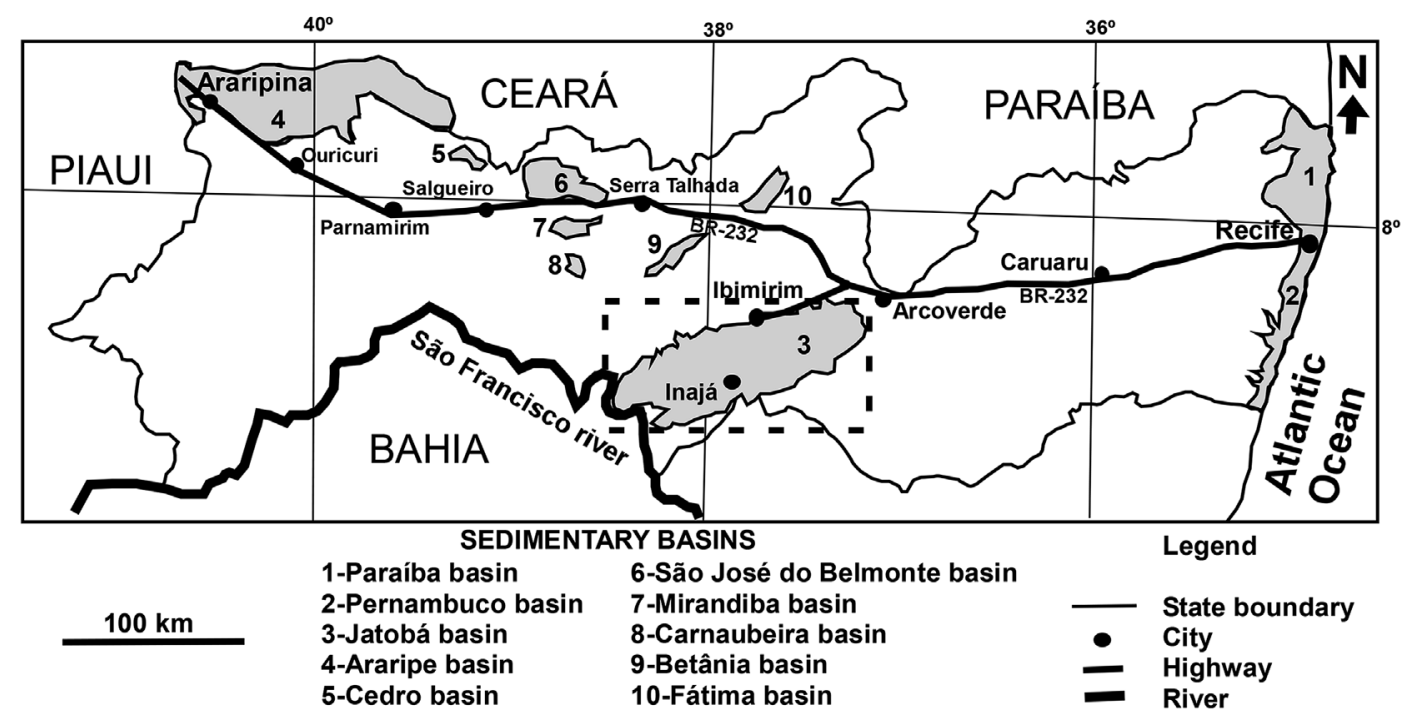

Fig. 2. Location map of the sedimentary basins of Pernambuco State. The marked rectangle represents the study area (Jatobá Basin, Figs. 3 and 17). Modified from Gomes. (2001).

\begin{tabular}{|c|c|c|c|c|c|c|}
\hline \multicolumn{3}{|c|}{ GEOCHRONOLOGY } & \multirow{2}{*}{$\begin{array}{l}\text { TECTO- } \\
\text { NIC } \\
\text { STAGE }\end{array}$} & \multirow{2}{*}{$\begin{array}{c}\text { STRATIGRAPHICAL } \\
\text { UNITS }\end{array}$} & \multirow{2}{*}{$\begin{array}{l}\text { DEPOSITIONAL } \\
\text { ENVIRONMENTS }\end{array}$} & \multirow{2}{*}{ LITHOLOGY } \\
\hline \begin{tabular}{|l} 
ERA \\
\end{tabular} & PERIOD & AGE & & & & \\
\hline \multirow{2}{*}{ 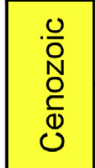 } & Neogene & $\begin{array}{l}\text { Pleisto- } \\
\text { cene }\end{array}$ & & Alluvium & $\begin{array}{l}\text { Fans and alluvial/ } \\
\text { fluvial terraces }\end{array}$ & $\begin{array}{l}\text { Sands, silts, clays and } \\
\text { conglomeratic lenses }\end{array}$ \\
\hline & $\begin{array}{l}\text { Paleo- } \\
\text { gene }\end{array}$ & $\begin{array}{l}\text { Oligo- } \\
\text { cene }\end{array}$ & & Eluvium/Colluvium & Residual rubble cover & Gravels and sands \\
\hline \multirow{10}{*}{$\begin{array}{l}.0 \\
\text { N } \\
0 \\
0 \\
0 \\
\mathbb{0} \\
\sum\end{array}$} & \multirow{8}{*}{$\begin{array}{l}0 \\
0 \\
0 \\
0 \\
0 \\
\frac{\pi}{0} \\
\frac{0}{0} \\
0\end{array}$} & $\begin{array}{l}\text { Albian/Ce- } \\
\text { nomanian }\end{array}$ & $\begin{array}{l}\text { Post- } \\
\text { Rift II }\end{array}$ & Exu Formation & $\begin{array}{l}\text { Fluvial meandering } \\
\text { and braided }\end{array}$ & $\begin{array}{l}\text { Coarse-grained to conglomaratic } \\
\text { sandstones with clayey lenses }\end{array}$ \\
\hline & & \multirow{3}{*}{ Aptian } & \multirow{3}{*}{$\begin{array}{l}\text { Post- } \\
\text { Rift I }\end{array}$} & Romualdo Formation & Shallow lacustrine & $\begin{array}{l}\text { Siltstone and shale at the base and } \\
\text { limestone and coquine at the top }\end{array}$ \\
\hline & & & & Crato Formation & $\begin{array}{l}\text { Shallow to deep } \\
\text { lacustrine }\end{array}$ & $\begin{array}{l}\text { Laminated limestones intercalated } \\
\text { with sandstones, marls and shales }\end{array}$ \\
\hline & & & & $\begin{array}{l}\text { Marizal } \\
\text { Formation }\end{array}$ & $\begin{array}{l}\text { Fluvial associated } \\
\text { to deltas }\end{array}$ & $\begin{array}{l}\text { Sandstones, siltstones and } \\
\text { claystones with load cast }\end{array}$ \\
\hline & & $\begin{array}{l}\text { Barre- } \\
\text { mian }\end{array}$ & \multirow{4}{*}{ Rift } & \multirow{2}{*}{$\begin{array}{l}\text { São Sebastião } \\
\text { Formation }\end{array}$} & \multirow{2}{*}{$\begin{array}{l}\text { Fluvial (high energy) } \\
\text { with eolic reworking }\end{array}$} & \multirow{2}{*}{$\begin{array}{l}\text { Coarse- to fine-grained sandstones } \\
\text { with pebbles at the base }\end{array}$} \\
\hline & & $\begin{array}{l}\text { Haute- } \\
\text { rivian }\end{array}$ & & & & \\
\hline & & $\begin{array}{l}\text { Valan- } \\
\text { ginian }\end{array}$ & & Uh & $\begin{array}{l}\text { Deltaic associated } \\
\text { to lacustrine }\end{array}$ & $\begin{array}{c}\text { Alternating medium to coarse-grained } \\
\text { sandstones with siltstones and } \\
\text { claystones }\end{array}$ \\
\hline & & $\begin{array}{l}\text { Berria- } \\
\text { sian }\end{array}$ & & $\begin{array}{l}\text { Candeias } \\
\text { Formation }\end{array}$ & $\begin{array}{l}\text { Shallow fluvial- } \\
\text { lacustrine }\end{array}$ & $\begin{array}{l}\text { Sandstones, shales and argillaceous } \\
\text { siltstones interfingering with carbonates }\end{array}$ \\
\hline & $\frac{u}{n}$ & \multirow{2}{*}{$\begin{array}{l}\text { Titho- } \\
\text { nian }\end{array}$} & \multirow{2}{*}{$\begin{array}{l}\text { Pre- } \\
\text { Rift }\end{array}$} & $\begin{array}{l}\text { Sergi } \\
\text { Formation }\end{array}$ & $\begin{array}{l}\text { Fluvial braided } \\
\text { with eolic reworking }\end{array}$ & $\begin{array}{l}\text { Coarse- to fine-grained sandstones } \\
\text { with laterite crusts }\end{array}$ \\
\hline & 䨔 & & & $\begin{array}{l}\text { Aliança } \\
\text { Formation }\end{array}$ & $\begin{array}{l}\text { Shallow lacustrine } \\
\text { with fluvial influence }\end{array}$ & $\begin{array}{c}\text { Shales and siltstones with fine-grained } \\
\text { sandstones, calcarenites and } \\
\text { gypsite intercalations }\end{array}$ \\
\hline \multirow{3}{*}{$\begin{array}{l}\frac{U}{O} \\
N \\
O \\
\frac{D}{N} \\
\square\end{array}$} & \multirow{2}{*}{ 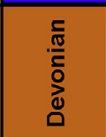 } & & \multirow{3}{*}{$\begin{array}{l}\text { Syne- } \\
\text { clise }\end{array}$} & $\begin{array}{l}\text { Inajá } \\
\text { Formation }\end{array}$ & $\begin{array}{c}\text { Shallow marine } \\
\text { plataformal associated } \\
\text { to fluvial }\end{array}$ & $\begin{array}{l}\text { Ferruginous fine-grained laminated } \\
\text { sandstones with siltstones and } \\
\text { coarse-grained sandstones }\end{array}$ \\
\hline & & & & \multirow[b]{2}{*}{$\begin{array}{l}\text { Tacaratu } \\
\text { Formation }\end{array}$} & \multirow[b]{2}{*}{$\begin{array}{l}\text { Fluvial braided } \\
\text { associated to } \\
\text { alluvial fans }\end{array}$} & \multirow[b]{2}{*}{$\begin{array}{l}\text { Coarse- to very coarse-grained } \\
\text { sandstones with ferruginous crusts }\end{array}$} \\
\hline & 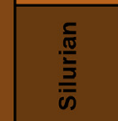 & & & & & \\
\hline $\begin{array}{l}\text { Prote- } \\
\text { rozoic }\end{array}$ & & & & $\begin{array}{l}\text { Crystalline } \\
\text { basement }\end{array}$ & & $\begin{array}{c}\text { Granites, migmatites, gneisses, } \\
\text { sienogranites, monzogranite and } \\
\text { quartzites }\end{array}$ \\
\hline
\end{tabular}

Fig. 3. Stratigraphic column of the Jatobá Basin (modified from Neumann et al., 2010). 


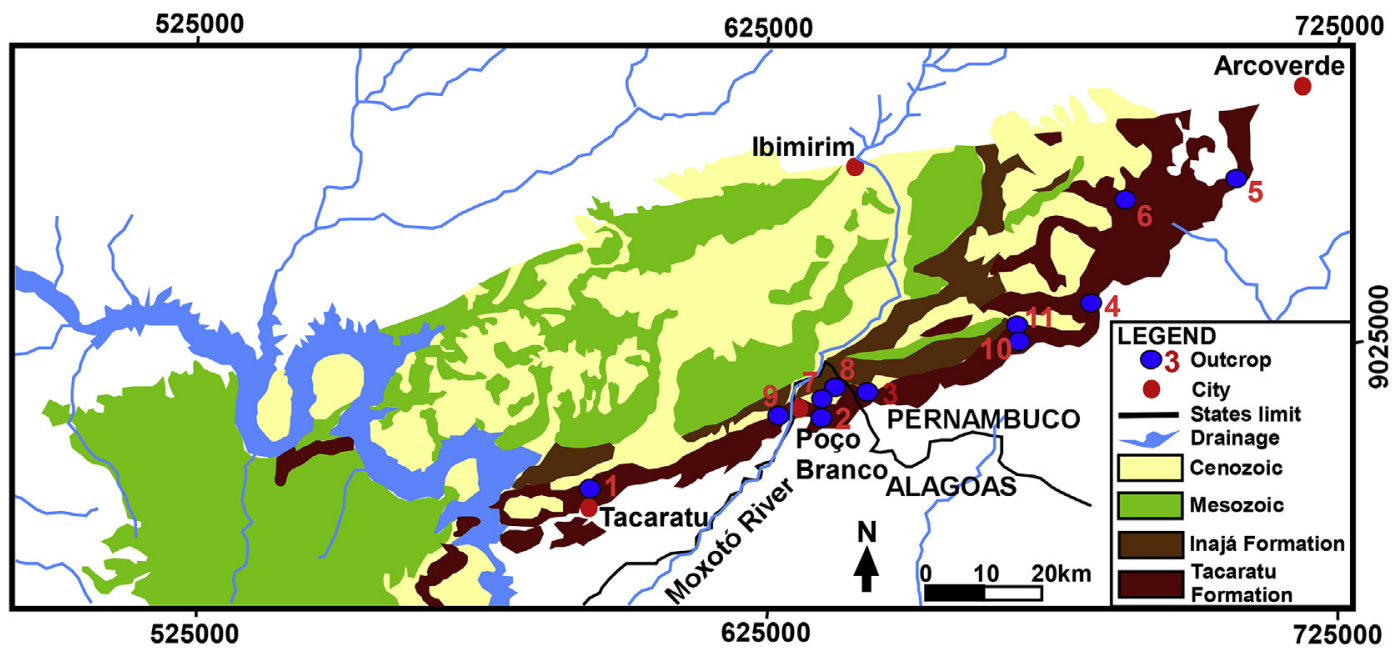

Fig. 4. Geologic map of the Jatobá Basin showing the Tacaratu Formation. Modified from Rocha and Leite (1999).

\section{Materials and methods}

The main objective of the fieldwork was a geological overview of the area, including the macroscopic description of eleven outcrops, identification of the largest possible number of representative facies of the sandstones of the Tacaratu Formation, definition of the boundaries between superimposed and overlapping geological units, measurement of palaeocurrents in six outcrops, faults, fractures and sedimentary structures.

In addition to the field work, the following laboratory analyses were undertaken:

(1) A petrographic analysis of 5 (five) thin sections of the crystalline basement for identification of lithological types present in the basal portion of the basin;

(2) A description of 20 (twenty) thin sections of the Tacaratu rock samples carried out based on Folk (1968); and

(3) A clay mineral analysis by X-ray diffraction in order to identify the clay minerals from the Tacaratu Formation.

\section{Results}

\subsection{Tacaratu formation}

The sandstones are generally white to pinkish red in colour, coarse to medium grained, locally fine grained, and comprised of angular to sub-rounded quartz grains. They can be locally extremely silicified.

In other portions of the basin, the sandstones crop out in isolated small hills. Exposures of small outcrops principally occur when associated with the overlying sediments of the Inajá Formation. Often these outcrops are covered by in-situ weathering deposits, which mask the gradual and concordant contact between the Tacaratu and Inajá formations.

In the field, several facies were identified in the Tacaratu Formation based on their textural characteristics, composition, colour and energy level.

The Tacaratu Formation is often found as coarse-grained sandstones, with tabular sets and fining upward cycles (Fig. 5). Other observed sedimentary structures include tabular sets and tangential crossstratification, with alternating energy levels. The identified cycles include high energy and low energy (Fig. 6).

In some places, as in Poço Branco (Alagoas State, Fig. 3), the sandstone has characteristics of a fluvial environment. The structures represented in this outcrop are tabular and tangentially cross-stratified and are truncated by pebbles and pavements of pebbles that fine

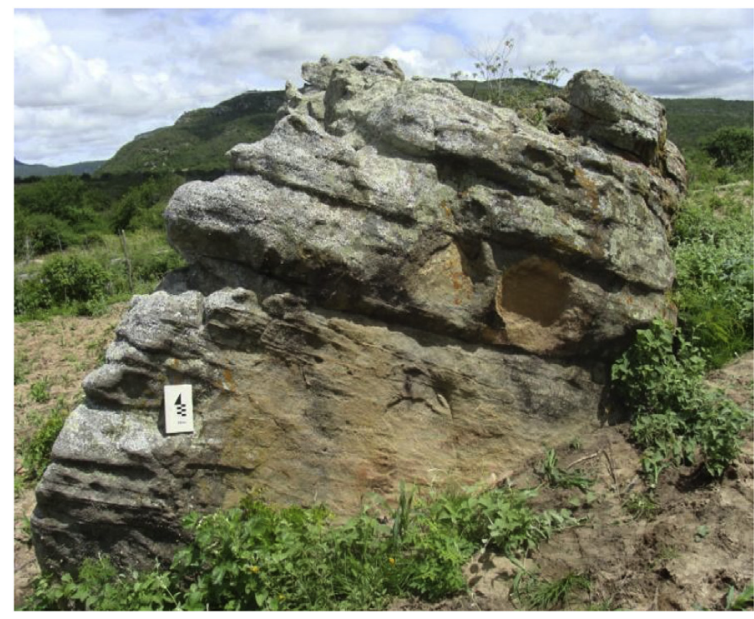

Fig. 5. Coarse-grained sandstone with tabular sets and tangential cross-stratification, Tacaratu Formation. Outcrop 3 in Fig. 4.

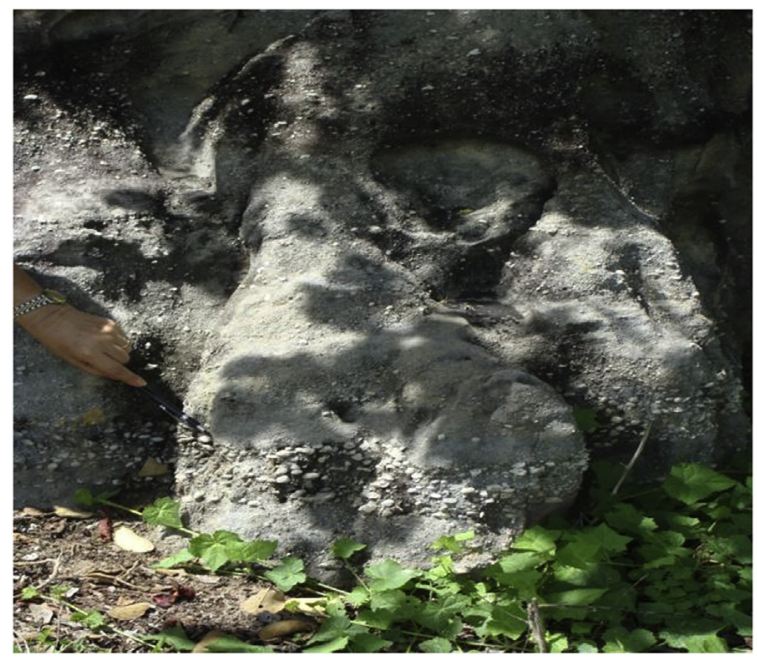

Fig. 6. Detail of the base of the outcrop showing sub-angular quartz grains, indicating high energy level and small transport distance. Outcrop 3 in Fig. 4. 


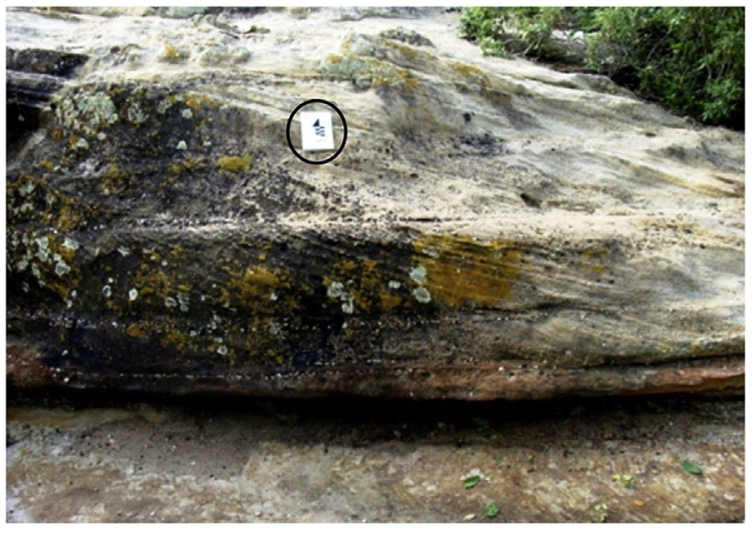

Fig. 7. Coarse-grained sandstones with tangential cross-stratifications; granule and pebble layers are visible at the base of the sets. Outcrop 2 in Fig. 4.

upwards (Fig. 7).

\subsection{Facies analysis}

The sedimentary facies identified in the Tacaratu Formation are distributed in practically all the investigated areas (Fig. 8). The facies are composed of coarse-grained sandstones and conglomerates that represent a braided fluvial system as defined by Cant and Walker (1978). Table 1 synthesizes the facies described below.

\subsection{Detrital composition, cements and mineralogic maturity}

The major constituents and accessories of the framework of sandstones and conglomerates of the Tacaratu Formation were identified and defined by grain size, rounding, contact between grains and cements as well as the defined mineralogical and textural maturity of these sandstones. Thus, the detrital composition is comprised of quartz, feldspar, muscovite, biotite, lithic fragments and opaque and heavy minerals.

The sorting of the Tacaratu Formation sandstones and conglomerates is usually moderate to poor, with less than $5 \%$ of the matrix.

The sandstones are dominantly quartzarenites (55\% of the samples) as seen below, but $35 \%$ were classified as sublitharenite and $10 \%$ as subarkose (Fig. 9). The quartz grains (average of 50\%) are mainly monocrystalline (average of 60\%) and commonly partially covered by overgrowths (Fig. 10). Polycrystalline grains are locally abundant (up to $17 \%$ ) but generally of greater size.

The feldspars (1-7\%; average of 3.5\%) are equally K-feldspar and plagioclase. Potassium feldspar may display widespread dissolution and replacement by kaolinite, illite and, more rarely, by albite. Microcline dominates over orthoclase/sanidine and perthite. Plagioclase grains appear in the same proportion as K-feldspar but frequently as fresh geminated ones. The lithic fragments (0-3\%; average of $2.7 \%)$ are essentially chert, quartzite and low-grade mica, schist/phyllite and sericite quartzite. Hydrothermal quartz with abundant fluids (semi-composite quartz grains; Fig. 10), gneissic and granitic rock fragments, as well as tourmaline and chlorite inclusions are significant only in the coarsest conglomerates. Micas are by far the most prominent accessory grains (2-10\%; average of $7.5 \%$ ) and are usually concentrated or showing preferred directions when biotite is extensively kaolinized. Tourmaline, zircon and rutile are more common than other heavy minerals, which could be altered during diagenesis. Fragments of the original, less stable heavy mineral assemblage, including epidote, hornblende, apatite, sphene and Fe-Ti oxides, are preserved in the micaceous fine sandstones and siltstones deposited in the cycle tops as well as dispersed in reduced amounts in the framework of the sandstones.
The grains are angular to subangular, but some samples exhibit subangular to subrounded grains. The samples have a textural maturity classified as submature (less than $5 \%$ of clay) in $75 \%$ of these sandstones. The grain size sorting ranges from moderate to poor in virtually all samples.

The lithotypes have few intergranular spaces (pores), with a predominance of concave-convex contacts, showing high compaction, with closed packing, derived from compression.

Quartz is the dominant detrital component, with straight extinction (main) and infrequent undulose extinction. The grain sizes range from fine-to medium-grained (smaller quantities) and medium-to coarsegrained, although, coarse-grained sandstones with clasticity indexes of approximately $60 \%$ predominate.

The quartz is dominantly monocrystalline (Qm), mostly fragments of the plutonic type, and may be derived from granitic rocks or recycled types (Fig. 11A). The second type of quartz is polycrystalline (Qp) with undulose extinction, and the third, semi composite type is typical of quartz veins or hydrothermal sources (Figs. 10 and 11A, B, E, F). Qm grains are xenomorphic, and some have inclusions of rutile (Fig. 11C), muscovite and zircon. Some grains are fractured, and the fractures are filled with silica (Fig. 11C), as discussed below.

The Qp type occurs in all samples, with a predominance of the metamorphic and deformed composite type (sheared-quartz) of Krynine (1940) and Scholle (1979). The grains are dominantly of the metamorphic composite type and constitute a mosaic of various crystals with straight edges. It features individualized grains and displays sutured contacts, suggesting the schistose metamorphic type of Krynine (1940), with abundant inclusions of mica.

The deformed composite type, which is sheared-quartz according to Scholle (1979, Fig. 11B), presents clear orientations and stretching of single crystals with irregular and sutured contours (Adams et al., 1993). The single crystals sometimes show preferred orientations. Some of these polycrystalline grains reach approximately $1.60 \mathrm{~mm}$, with a predominance of undulose extinction (Fig. 11B) and sub rounded grains. Sheared-quartz can represent a source that underwent instead of suffered a high degree of deformation and/or metamorphism.

The semi-composite quartz type occurs in a smaller proportion than the metamorphic or deformed composite polycrystalline quartz type. The semi-composite quartz consists of two or more whole grains, with evidence of recrystallization, presenting well-formed contacts between the grains (straight and polyhedral) (Figs. 10 and 11A, B, E, F). This variety of quartz with a predominance of undulating extinction indicates the origin of the sources is derived from hydrothermal veins and lodes (milky quartz).

The feldspars are less abundant in these sandstones, and when they occur, the percentage of both varieties of plagioclase and microcline (Kfeldspar) does not exceed $7 \%$ of the total rock. The average percentage of occurrence of the two feldspar types is approximately $3 \%$. For these two types, it was found that microcline (K-feldspar) occurs more frequently.

Microcline grains usually occur as a few fresh grains, but they are identifiable by the typical grid-twinning (Fig. 12B). Some others are altered and dirty, making identification difficult. It normally forms subhedral to anhedral grains and for the most part is altered to instead of for sericite.

Plagioclase appears fresher than the K-feldspar, and subrounded grains are dominant, and sometimes included in polycrystalline quartz grains (Fig. 13B).

The mica group is represented practically by muscovite grains and occurs in $95 \%$ of the thin sections studied, with a percentage of $7.5 \%$. Muscovite often appears curved, bent, deformed, and possibly shows effects of compression or greater degrees of diagenesis (Fig. 11A). Muscovite grains occur in large flakes (Fig. 14A), sometimes partially covering quartz grains, and at other times, they are included in quartz as small inclusions (Fig. 13A). They usually are concentrated or show a preferred direction. On the other hand, biotite grains rarely occur and 

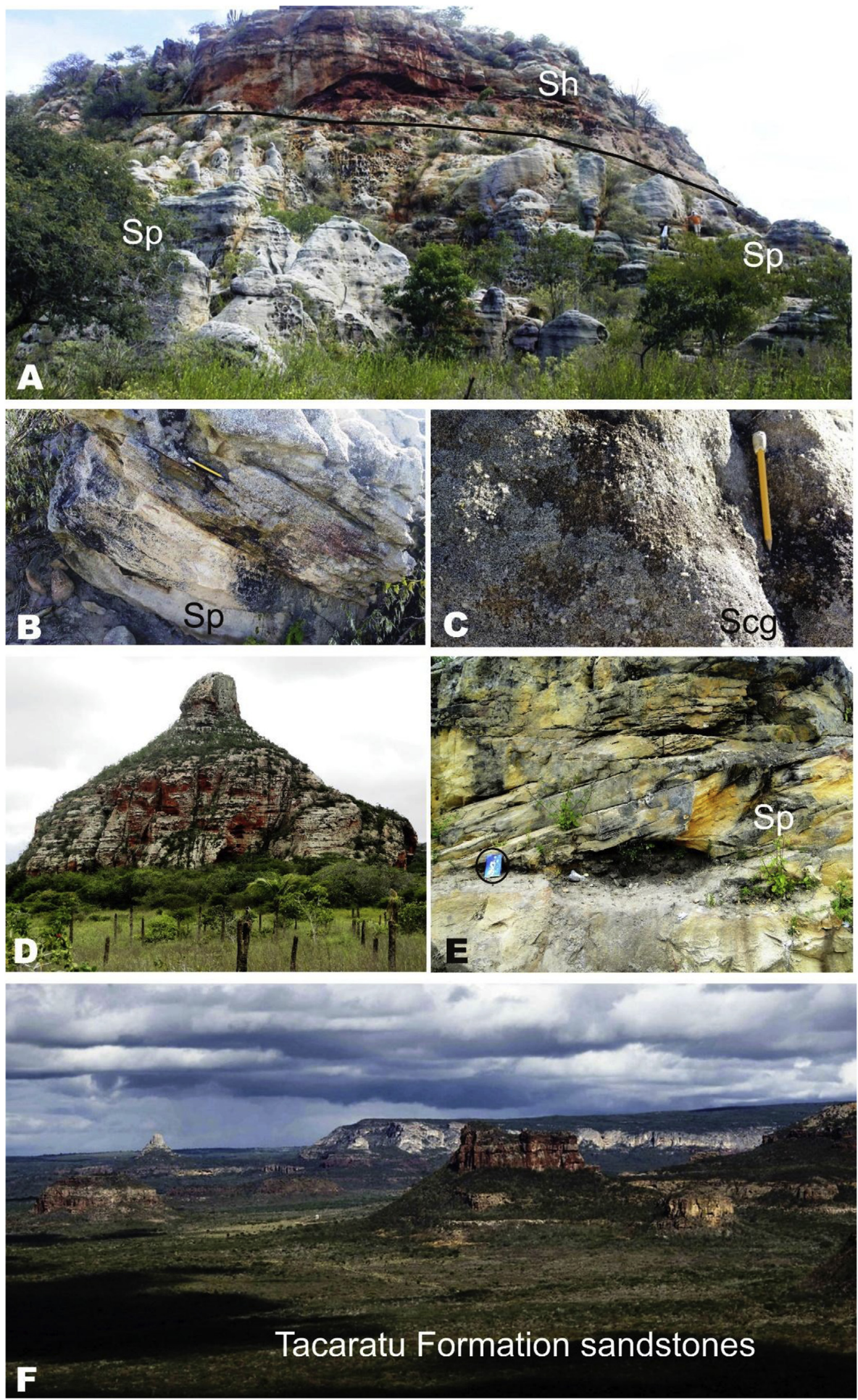

Fig. 8. Facies of the Tacaratu Formation; (A), aspect of the coarse-grained sandstones with tabular stratification of facies Sh, similar to the coarse-grained to conglomeratic sandstones with planar cross-stratification of the facies Sp; (B), coarse-grained silicified sandstones of facies Sp; (C), coarse-grained to conglomeratic sandstones of facies Scg; (D), general aspect of the Sh facies sandstones, which show characteristic weathering forms; (E), well-stratified medium-grained sandstones of facies Sp; (F), view of the Catimbau Valley, Pernambuco, showing the erosional forms of the Tacaratu Formation. 
Table 1

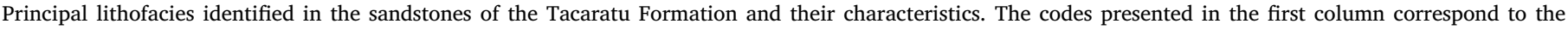
nomenclature proposed by Miall (1978, 1996).

\begin{tabular}{|c|c|c|c|}
\hline Lithofacies code & Facies & Sedimentary structures & Interpretation \\
\hline $\mathrm{Gm}$ & $\begin{array}{l}\text { Clast supported conglomerates, poorly } \\
\text { stratified }\end{array}$ & Planar bedding, imbrications & Longitudinal bars, lag deposits \\
\hline Gt & Tangential cross-stratified conglomerates & Tangential cross- stratifications & $\begin{array}{l}\text { Deposited from traction by a unidirectional current. Gt Facies indicates deposits } \\
\text { of migrating subaqueous dunes with sinuous crests (3D dunes and bars) under } \\
\text { lower flow regime conditions }\end{array}$ \\
\hline Gp & $\begin{array}{l}\text { Cross-stratified clast supported } \\
\text { conglomerates }\end{array}$ & Planar cross- stratifications & Longitudinal bars, old growth remaining bars \\
\hline Scg & $\begin{array}{l}\text { Cross-stratified pebbly and conglomeratic } \\
\text { sandstones }\end{array}$ & Tangential cross-stratifications & $\begin{array}{l}\text { Deposits of migrating subaqueous dunes with sinuous crests (3D dunes and bars) } \\
\text { under lower flow regime conditions }\end{array}$ \\
\hline St & $\begin{array}{l}\text { Coarse- to medium-grained sandstones } \\
\text { with tangential Cross-stratifications }\end{array}$ & $\begin{array}{l}\text { Solitary or grouped tangential } \\
\text { cross- stratifications }\end{array}$ & $\begin{array}{l}\text { Dunes (lower flow regime). Channel fill and lateral migration of sandy and } \\
\text { gravel bars }\end{array}$ \\
\hline Sp & $\begin{array}{l}\text { Coarse- to medium-grained sandstones } \\
\text { with planar cross- stratifications }\end{array}$ & $\begin{array}{l}\text { Solitary or grouped planar } \\
\text { cross- stratifications }\end{array}$ & $\begin{array}{l}\text { Planar-cross stratification related to 2D subaqueous sand dunes along transverse } \\
\text { linguoid bars and sand waves under upper flow regime conditions }\end{array}$ \\
\hline Sh & Horizontally stratified sandstones & Planar stratification & Planar stream bed (upper flow regime) \\
\hline
\end{tabular}

The group of facies Gm, Gt, Gp and Scg are characterized by clast-supported conglomerates and troughs as well as planar cross-stratified conglomerates and conglomeratic sandstones. These facies indicate channel fills and the lateral migration of sandy and gravel bars, although trough and planar cross-stratifications can represent lateral and longitudinal accretion bars of braided channels. The Scg, St and Sp facies represent deposits formed by the migration of longitudinal bars in braided river channels. The Sh facies (planar stratified sandstones) suggests planar bedding flow formed from an upper flow regime and giving rise to planar bed forms.

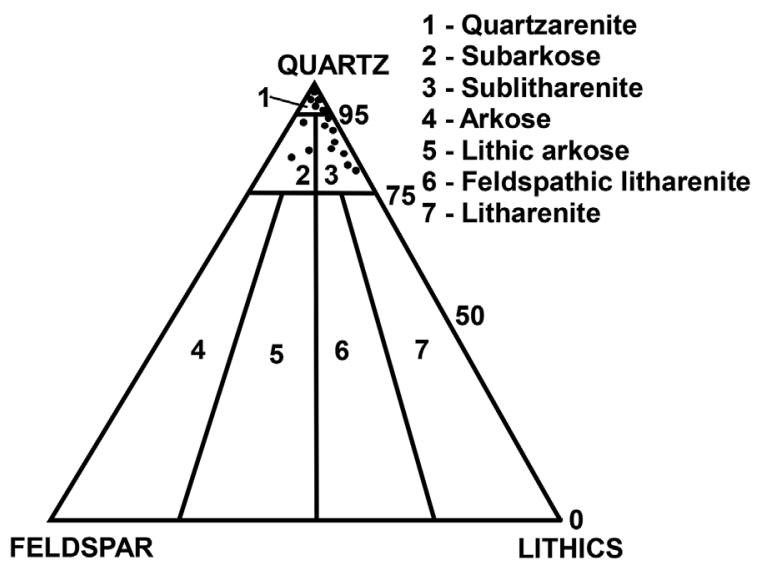

Fig. 9. Framework compositions of twenty sandstone samples of the Tacaratu Formation. Folk, 1968.

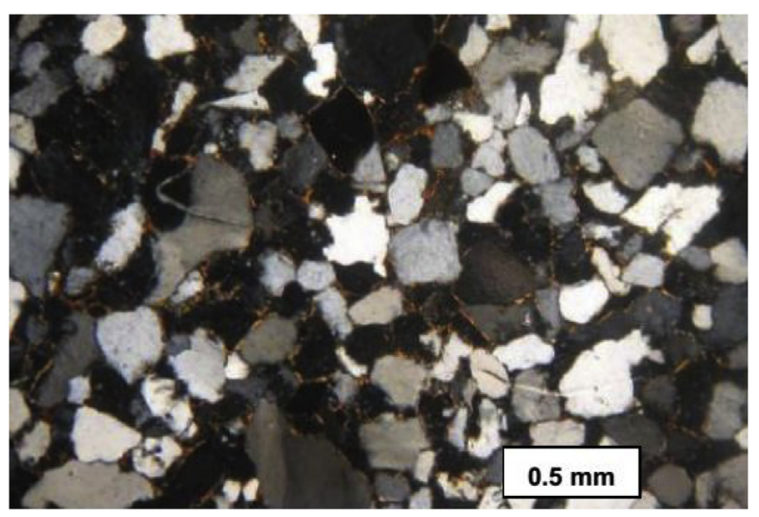

Fig. 10. Thin section showing a Tacaratu Formation sandstone; (A), a framework of quartz arenite exhibiting predominant monocrystalline quartz grains (Qm) of xenomorphic habit, semi-composite qz (Qps), opaque minerals and siliceous and ferruginous cement. Scale $=0.50 \mathrm{~mm}$ Magnification $10 \mathrm{x}$, $\mathrm{Nx}=$ polarized nicols. White bar for scale.

are present open ends, indicating alteration (cloritization).

Muscovite and biotite grains are derived from various igneous rocks but primarily originate from metamorphic rocks such as phyllites and schists. Although biotite is more common in the source area in relation to muscovite, the latter is more stable chemically and, therefore, more common.

Lithic fragments are less significant than the feldspars, with a percentage of approximately $2.7 \%$ and are disseminated in the framework of the sandstones and conglomerates. They are mainly chert clasts as rounded to subrounded grains with dimensions between 0.4 and $0.8 \mathrm{~mm}$. The other fragments that are found are basically quartzose, probably metamorphic lithoclasts (quartzite), and micaceous fragments (schists and phyllites) that are oriented according to the elongation of the grains.

Clay minerals are rare. Some thin sections show the presence of probable kaolinite and illite. Other clay minerals present are infiltrated clays (Fig. 14B) and are discussed below.

Opaque minerals found were magnetite and hematite, and heavy minerals grains more common are zircon, tourmaline, titanite, epidote and rutile, representing $7 \%$ of the framework of samples. Despite the latter that constitute only $1 \%$ of framework, the presence of these minerals is constant, mainly zircon and tourmaline.

The ultra-stable heavy minerals (ZTR index) occur in grain form, mostly prismatic, with rounded edges. The rutile only occurs as inclusions in quartz in the form of needles, (Fig. 11C). Tourmaline grains are larger than zircon, sometimes measuring $0.48 \mathrm{~mm}$, are usually greenish or blueish in colour and have prismatic habit (Fig. 15A). Tourmaline grains occur isolated or instead of as included in quartz grains (Fig. 11D) and have small dimensions. Zircon usually appears in quartz grains of prismatic shape (Fig. 15B).

Detrital epidote grains are much less abundant than zircon and tourmaline, and their occurrence is punctual as rounded grains in quartz grains (Fig. 15C and D).

The cementation present is mainly siliceous and, to a lesser proportion, ferruginous. The siliceous cement occurs as (1) secondary quartz overgrowth in the intergranular mosaic, and, subordinately, (2) in the form of fibrous chalcedony.

Partial dissolutions along intergranular contacts and stylolites occur as the main quartz cement in Tacaratu sandstones. The pressure between quartz grains in intergranular contacts caused the partial dissolution of quartz grains, culminating in instead to the collage of grains and gave rise to stylolites.

Quartz overgrowths (siliceous cement) are common, with an average of $5 \mathrm{vol} \%$ (up to 14\%). Despite the absence of trapped oxides and clays, the overgrowths could be discriminated from the host grains. Quartz overgrowths occur in some samples between grains and before considerable compaction, whereas in others, they precipitate after 


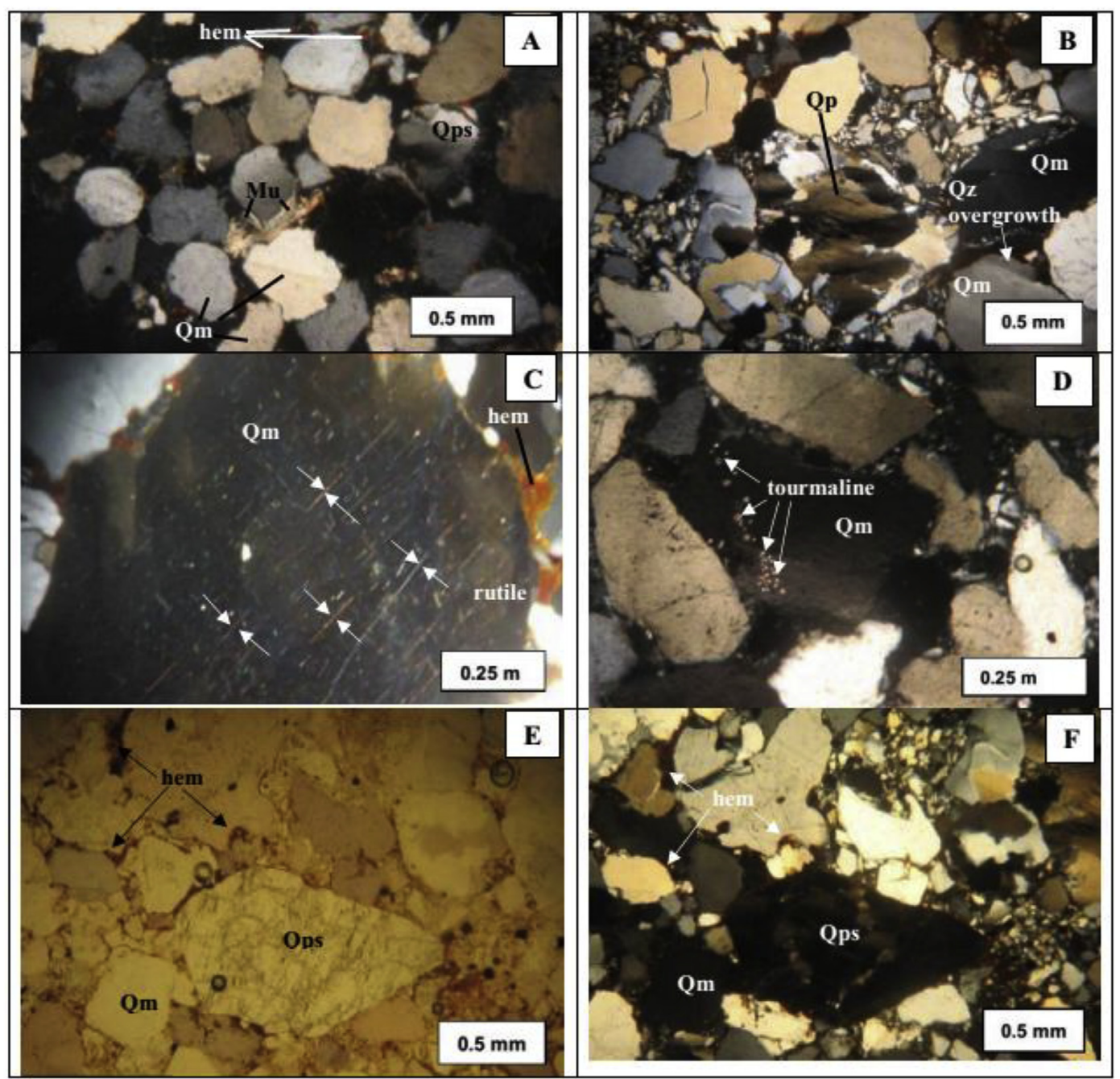

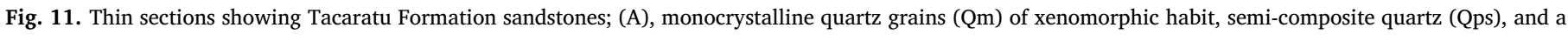

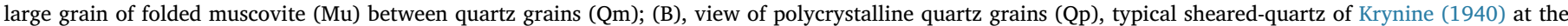

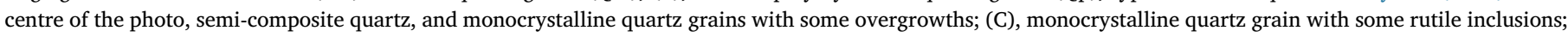

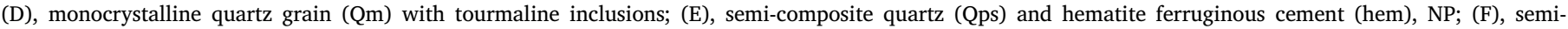
composite quartz (Qps) and hematite ferruginous cement (hem), Nx. Scale $=0.25$ and 0.50 mm. Magnification $5 x$ and $10 x$, Nx $=$ polarized nicols.

intense pressure dissolution (Fig. 11E and F). The overgrowths show dull-brown luminescence and complex zonation (Fig. 11A). Authigenic quartz locally replaces detrital quartz along fractures and along the contacts between overgrowths and host grains (Fig. 11A) (Morad et al., 2000; De Ros et al., 1994; De Ros, 1998). These facts suggest that some dissolution of detrital quartz occurred during or after mechanical compaction and before extensive cementation (Morad et al., 2000). Prismatic quartz outgrowths occupy intra- and intergranular pores (0-4\%; average of $2 \%)$. This morphology is very common in late mesogenetic quartz (McBride, 1989; De Ros et al., 1994). Well-developed multiple overgrowths and outgrowths engulf illite, which on the other hand cover earlier-formed overgrowths (Figs. 11D-12B), demonstrating the presence of at least two main quartz cement generations.

The ferruginous cement is observed around the grains (Figs. 10 and $11,12 \mathrm{~A}, \mathrm{~B}, 13 \mathrm{C})$ in the form of hematite coatings and fringes with strong reddish (iron oxide) and yellowish colours and, subordinately, illite.

Illite is common in the Tacaratu Formation ( $0-4 \%$; average of 3\%), occurring mostly as aggregates of lamellar crystals that replaced vermicular kaolin, feldspar grains, micas and the pseudo matrix. Rims and divergent aggregates of fibrous or lath-shaped crystals are less widespread, but they are locally abundant and associated with late quartz overgrowths and outgrowths. In the outcrop samples, however, illite and kaolin commonly occur together, and illite pseudomorphically replaces partially dissolved vermicular kaolin.

The presence of mainly siliceous and subordinately ferruginous cements indicates diagenetic dry or semi-arid climate conditions.

The packing on most thin sections (13 sections) is tight and is expressed by contacts among the grains of the concave-convex, planar and sutured types. Four thin sections showed normal packing, with just one thin section with loose packing, expressed by polygonal contacts in the majority.

Based on these results, it follows that such a framework arrangement (tight and normal), means a greater effect of rock compaction, probably related to the much larger thickness of burial.

In this work the mineralogical and textural maturity were studied.

The mineralogical maturity of the sandstone was inferred from the presence of heavy minerals and the quantity of quartz in the matrix, which was comprised of $\geq 90 \%$ stable minerals. Based on that percentage, the results indicate that $65 \%$ of the sandstones are super mature and that $35 \%$ are mature and comprised of $<90 \%$ stable minerals.

In the textural maturity, the grain/matrix ratio was observed.

A majority of the samples (75\%) are texturally sub-mature with low clay content $(<5 \%)$. The remaining samples $(25 \%)$ were classified as 


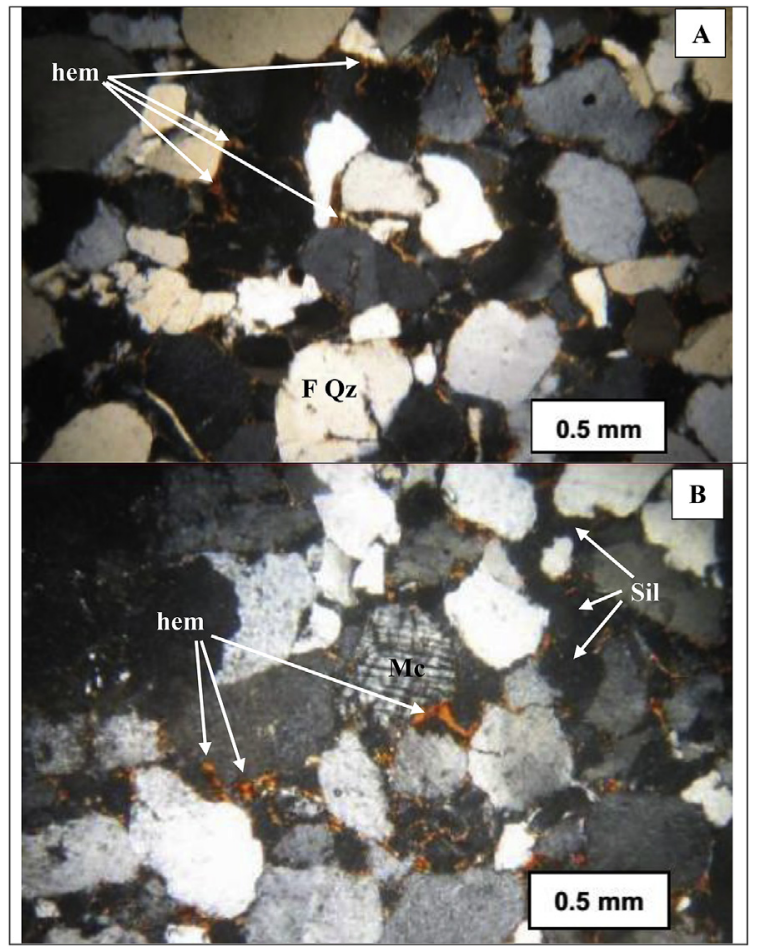

Fig. 12. Thin section showing Tacaratu Formation sandstones; (A), fractured quartz (FQz) grain and ferruginous cement (hem, orange); (B), microcline (Mc) grain, ferruginous (hem) and siliceous (Sil) cement. Note the predominance of the monocrystalline type of quartz. White bar for scale.

mature with little or no clay content.

The classification of lithotypes was based on the diagram by Folk (1968) with the following results (Fig. 9): 55\% of the samples were classified as quartzarenite, $35 \%$ as sublitharenite and $10 \%$ as subarkose. Of the eight samples analysed using the Folk Classification, five samples have a small fraction of kaolinitic clay. Quartz is the dominant mineral in all of the samples. Some samples contain fractured quartz grains, mono and polycrystalline quartz, quartz with inclusions, ferruginous and siliceous cements, and muscovite (Figs. 12 and 13).

\subsection{Provenance and tectonic environment}

The results of the sandstone analysis indicate that $60 \%$ of the grains are comprised of monocrystalline quartz $(\mathrm{Qm})$ and that $20 \%$ are comprised of polycrystalline quartz (Qp). These quartz-rich sands have a high Qm/Qp value. High-grade metamorphic polycrystalline quartz grains compose one type of polycrystalline quartz (Qp) (Figs. 11C-12B) indicative of metamorphic source.

Among the feldspars, the proportions of plagioclase and microcline is equal, and each compose $3 \%$ of the grains. Lithic fragments are scarce and make up $3 \%$ of the grains. Lithic fragments are siliciclastic and mostly chert fragments, with smaller amounts of metamorphic quartzite fragments and micaceous schist fragments.

According to De Ros (1985), the scarcity of lithic fragments in sandstones is due to the continuous reworking and granular comminution far from the principal sediment source.

The most abundant accessory minerals of these sandstones are micas, which constitute $6 \%$ of the grains. Muscovite lamellae are bent as a result of compaction. In addition, biotite, when present, is altered to chlorite.

Heavy opaque minerals are representative of these sandstones and constitute $7 \%$ of the matrix. They include magnetite and hematite. Ultra-stable minerals, including zircon and tourmaline, make up $1 \%$ of the matrix. Epidote is the least abundant heavy mineral in these

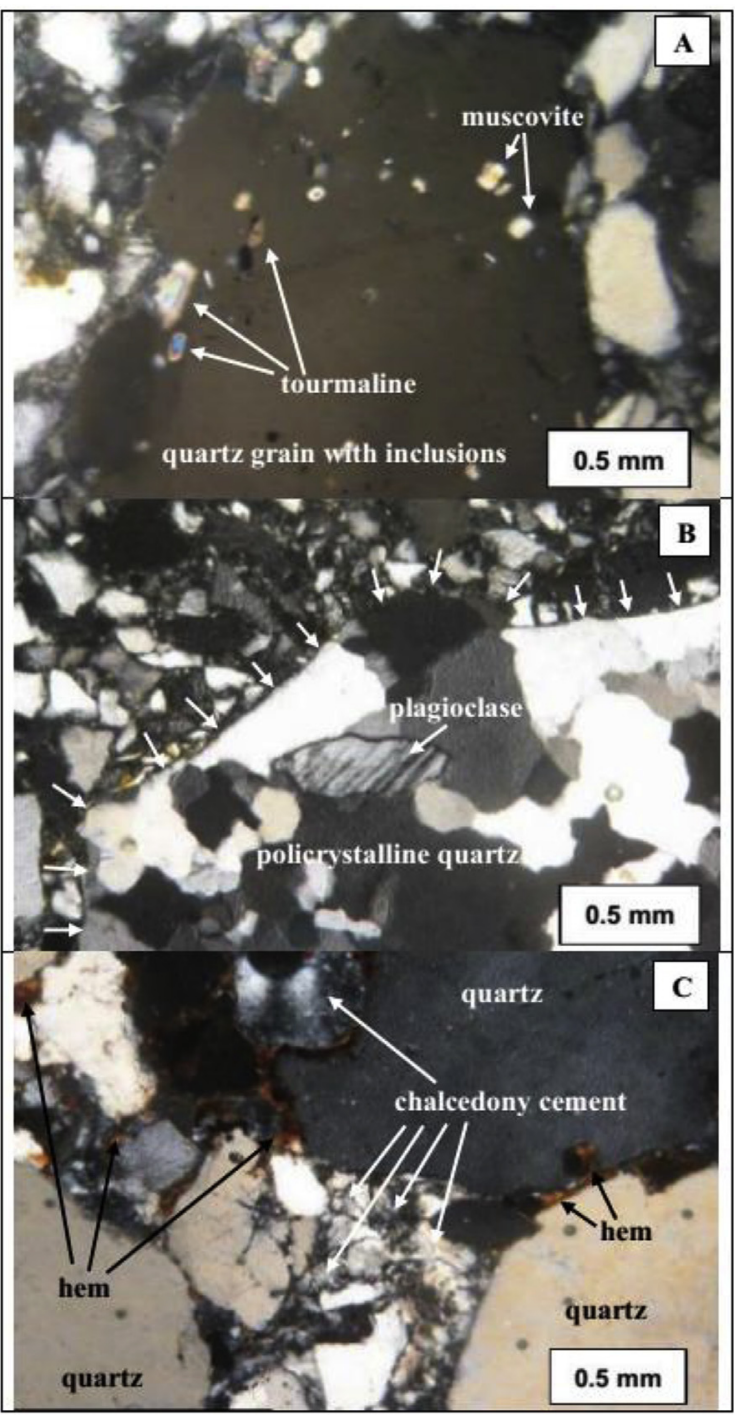

Fig. 13. Thin section showing Tacaratu Formation sandstones; (A), quartz grains with inclusions of tourmaline and muscovite; (B), plagioclase grain included in a high-grade metamorphic polycrystalline quartz grain (white arrows show the quartz grain boundary); (C), chalcedony and iron oxide (hem) cements partially covering quartz grains. White bar for scale.

sandstones.

Of the four types of provenance proposed by Dickinson and Suczek (1979), Dickinson et al. (1983) and Dickinson (1985), the model that is most similar to the detrital composition of the sandstones of the Tacaratu Formation is that of a stable craton provenance, with low-intensity tectonic events on the edge of the basin (Fig. 16).

The composition of these sandstones is not only conditioned by the matrix rocks but also by tectonic environment, climate, relief of the source area, transport conditions, depositional environment and diagenesis.

The mineralogical characteristics of the Tacaratu Formation indicate a sediment source of high-grade metamorphic rocks and igneous rocks of the crystalline basement situated in the central portion of the Pernambuco-Alagoas terrain and the eastern portion of the São Francisco craton. This is inferred from the abundance of quartz, muscovite, zircon, tourmaline and epidote. The climate and relief area of the sediment source as well as the transport conditions and depositional environment resulted in local variations in the sediments. The hot and humid climate and low relief of the source area are inferred from the alteration of feldspars and biotite, which are chemically unstable. 


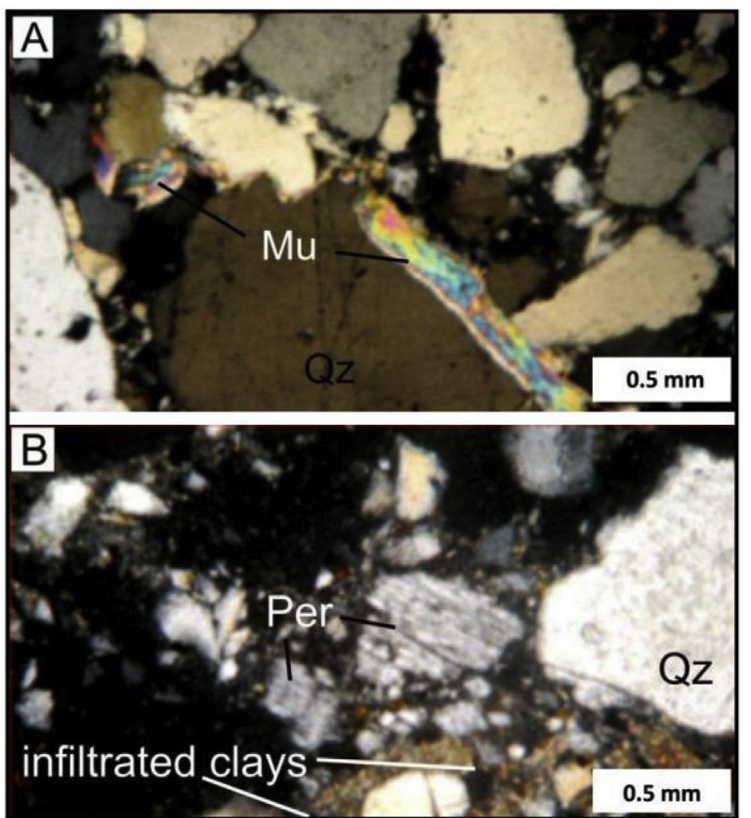

Fig. 14. Thin sections showing Tacaratu Formation sandstones; (A), large grain of muscovite $(\mathrm{Mu})$ between quartz grains $(\mathrm{Qz})$; $(\mathrm{B})$, perthite (Per) surrounded by quartz grains and infiltrated clays. Scale $=0.50 \mathrm{~mm}$. Magnification $10 \mathrm{x}$, $\mathrm{Nx}=$ polarized nicols. White bar for scale.

The source of the sediments as igneous and high-grade metamorphic terranes is inferred from the monocrystalline quartz grains and fragments of metamorphic schists, micas, and heavy minerals (zircon, tourmaline and epidote).

Muscovite grains arrived in the basin with little or no chemical alteration that revealed a short transport distance for these fragments and a short exposure time to the sedimentary environment. The sub-angular texture of the grains also indicates that these fragments were not transported far from the sediment source before reaching the basin.

\subsection{Diagenesis}

Through the petrographic study and X-ray diffractometry, the diagenetic history of the Tacaratu Formation was developed in the regimes of eodiagenesis, mesodiagenesis and telodiagenesis.

The beginning of eodiagenesis is marked by grain-coating, red iron oxide cements. This cement may have originated after the recently deposited sediment was still in contact with the local environment. The second stage of eodiagenesis is marked by mechanical compaction, resulting in the constant presence of folded and rotated micas. In the final stage of eodiagenesis and the beginning of mesodiagenesis, burial and chemical compaction became more effective, enhanced by concaveconvex and sutured contacts of the grains and with close packing and interpenetration of the grains.

The beginning of mesodiagenesis is represented by the secondary growth of quartz (scarce) and cementation by silica.

According to De Ros and Moraes (1984), McBride (1989), and De Ros et al. (1994) and De Ros (1998) there are four main sources of silica for quartz cementation in sandstones: (1) the dissolution or alteration of detrital silicates, mainly of feldspars, by meteoric waters; (2) the pressure dissolution of detrital quartz along intergranular contacts and stylolites; (3) the illitization of smectitic clays in subjacent or adjacent shales and (4) the rising of hot fluids related to rifting and magmatism.

The telodiagenetic environment (or weathering) was intensely active in these deposits and greatly modified their character. Unstable minerals underwent instead of suffered major alterations in the hot and humid climatic environment. The ferruginous cement and kaolinite are
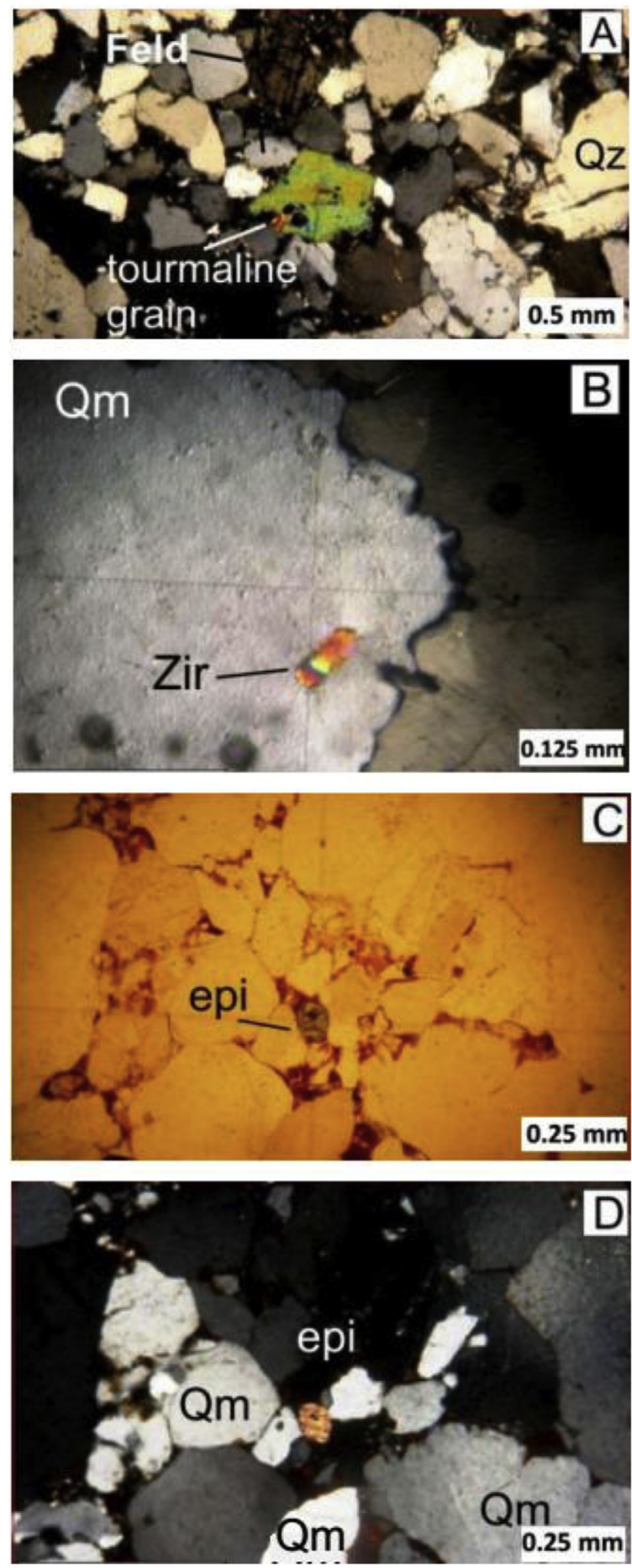

Fig. 15. Thin sections of Tacaratu Formation sandstones; (A), tourmaline crystal in the midst of quartz grains $(\mathrm{Qz})$. Scale $=0.50 \mathrm{~mm}$. Magnification $5 \mathrm{x}$, $\mathrm{Nx}=$ polarized nicols; (B), crystal of zircon included in large polycrystalline grain of quartz with sutured contacts. Scale $=0.125 \mathrm{~mm}$. Magnification 20x, $\mathrm{Nx}=$ polarized nicols; (C), (D), epidote grain among quartz grains, with rounded grains. Scale $=0.25 \mathrm{~mm}$. Magnification $10 \mathrm{x}, \mathrm{NP}=$ parallel nicols, $\mathrm{Nx}=$ polarized nicols. White bar for scale.

evidence of the telodiagenetic environment.

The rare and heavily altered feldspar grains are observed together in the studied thin sections. The exposure of these minerals to weathering intensified their alteration to produce partially sericitized or kaolinized feldspars (the latter was confirmed by X-ray diffractometry).

The diagenesis of these sandstones varies from medium to strong, 


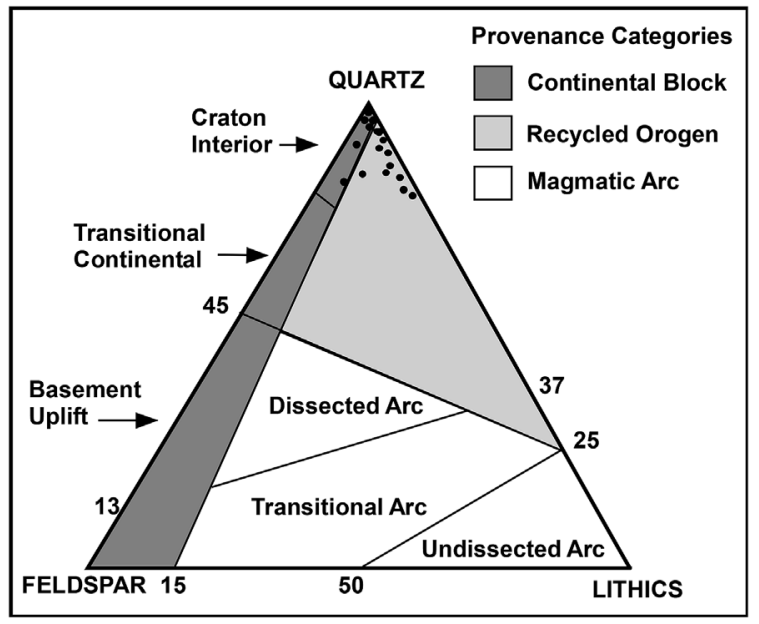

Fig. 16. The provenance Dickinson I diagram (Dickinson, 1985), showing the main contribution of the craton interior and subordinate contribution of recycled orogen provenance to the sandstone samples of the Tacaratu Formation in the Jatobá Basin.

according to the contacts between grains, the presence of curved and folded micas and the silicification of the formation.

These rocks were subjected to modifications of the matrix composition during diagenesis, silica alters readily into other forms, dissolves, and reprecipitates repeatedly throughout the history of these sandstones. There was a loss of feldspars, lithic fragments and small accessory minerals due to the processes of substitution and dissolution that occurred after deposition of the sediments.

\subsection{Palaeocurrents}

The measured palaeocurrents of the Tacaratu Formation were collected on the foresets of planar and trough cross-stratifications of moderate to large size. The palaeocurrent data were collected at six selected stations distributed along the entire exposures of the Tacaratu Formation.

The measured palaeocurrent indicators have a dominant trend from NW to N and a subordinate trend to the NE. The general trend of the palaeocurrents in this unit is northwest, as shown in Fig. 17.

The collected palaeocurrent measurements (Fig. 17) suggest source areas situated to the SE and S, flowing from the areas of the São Francisco Craton and the Pernambuco-Alagoas terrain where more resistant terranes of the Borborema Province are situated (Ponte, 1992; Arai, 2006). The provenance analysis developed in this work indicates a sediment source of high-grade metamorphic rocks and igneous rocks of the crystalline basement, situated in the southern portion of the basin.

\section{Discussion and conclusions}

The sandstones of the Tacaratu Formation are mostly quartzarenites, with a smaller portion of sublitharenite and subarkose sandstones.

Quartz with straight extinction is the predominant detrital component. The grains vary from fine to medium (smaller fraction) and from medium to coarse. Coarse-grained sandstones are most common, with a clasticity index of approximately $60 \%$. The majority of grains are angular to sub angular, and $75 \%$ of the samples are classified texturally as sub-mature, with less than $5 \%$ clay content.

Quartz is mainly monocrystalline (60\%), dominated by plutonic fragments that may have been derived from gneisses and migmatites or recycled sediments. Polycrystalline quartz (20\%) in the samples has undulating extinction. According to the results from analysed sandstone samples, they were derived from quartzose sands rich in total quartz $(\mathrm{Qt}=\mathrm{Qm}+\mathrm{Qp})$ with high levels of Qm/Qp. These sandstones are classified as super-mature to mature according to their mineralogical maturity, using the classification of Folk (1968).

The provenance of the rocks of the Tacaratu formation corresponds to the tectonic environment of a stable craton according to the classification of Dickinson (1985). The mineralogical characteristics of these sandstones indicate a sediment source of high-grade metamorphic rocks and igneous rocks of the crystalline basement situated in the southern part of the basin. Evidence for this provenance includes the abundance of quartz as well as the presence of other minerals such as muscovite, zircon, tourmaline and epidote.

The Tacaratu Formation covers the eastern and a small portion of northern margins of the Jatobá Basin. This unit represents a remnant of the high sedimentation levels of the synclinal stage present in the neighbouring basins of Parnaíba, Araripe and other interior basins of NE Brazil (Mabesoone, 1977). As these occurrences are correlated, the dispersion of palaeocurrent trends towards the NNW (Fig. 17) is consistent with the patterns obtained by Braun (1966) and Assine (1994, 2007).

In accordance with previous works (Braun, 1966; Ghignone, 1972; Caputo and Crowell, 1985; Ponte and Appi, 1990; Caixeta et al., 1994; Assine, 1992, 1994; 2007; Fambrini et al., 2013; Guzmán-González et al., 2015), according to the lithological similarity, palaeocurrent

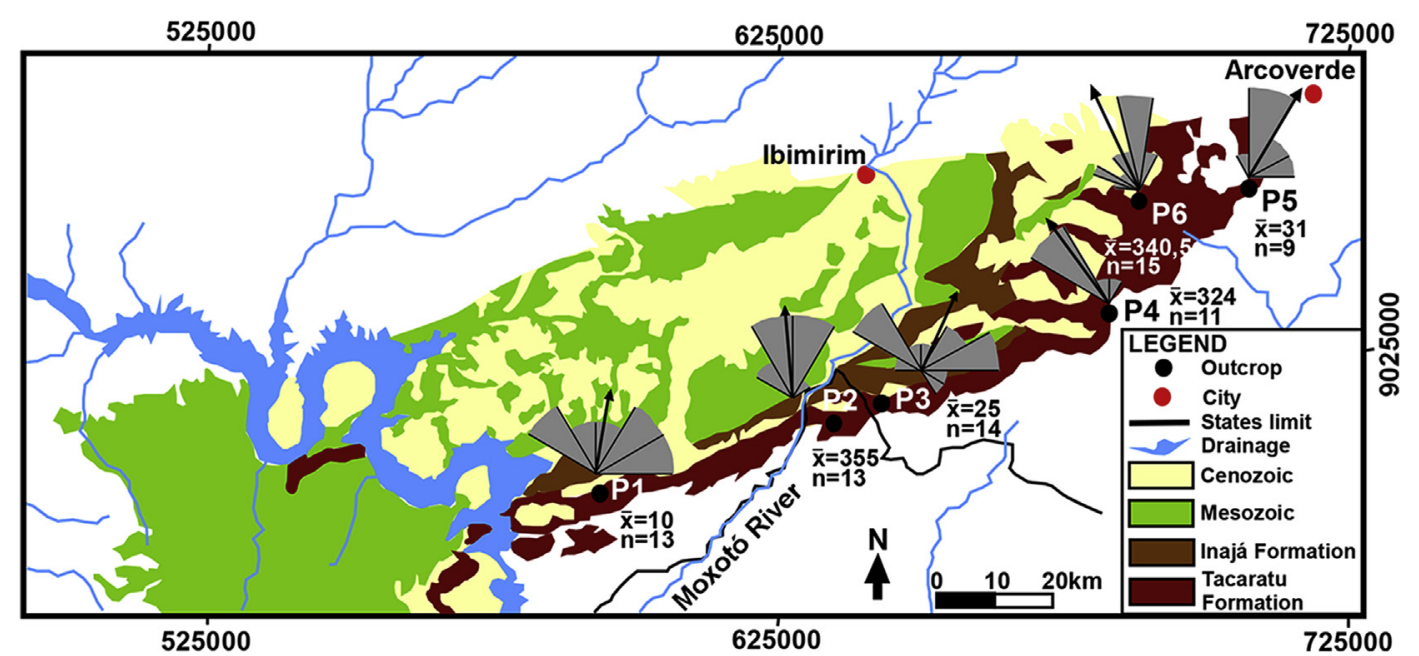

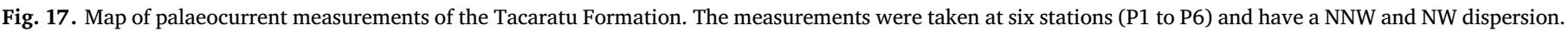
The location is the rectangle marked on Fig. 2. 
pattern and stratigraphic position, the Tacaratu Formation was positioned in the Lower Palaeozoic, possibly in the Silurian-Devonian interval or even in the Ordovician. According to those works, the unit was correlated with the Ipu Formation of the Serra Grande Group (Parnaíba Basin) and other sediments of the same period in the interior basins of the Northeast, including São José do Belmonte, Mirandiba, Betânia, Tupanaci, Cedro, Fátima and Bom Nome, as well as the Jatobá basin and the Northern and Central Tucano Basins, where it was originally named Tacaratu Formation. Following the same line of reasoning, Ghignone (1972) evaluated which units correlate with the Serra Grande Group, arguing that they originally belonged to the Parnaíba Basin, which in the Silurian reached the Cariri Valley of the Araripe Basin and the Jatobá basin, i.e., much further than its current eastern limit. That point of view was accepted by various authors, including Caputo and Crowell (1985), Ponte and Appi (1990) and Assine (1992, 2007). Recently, Souza-Lima et al. (2011) distinguished the Batinga Formation and the Karapotó Formation, which was denoted as the basal unit of the Sergipe-Alagoas Basin. This newly defined unit is texturally, faciologically and stratigraphically correlated with the Tacaratu Formation (Souza-Lima et al., 2011; Guzmán González et al., 2015). This suggestion had already been made by Barreto (1968), who identified the lithological similarity between the then Manari Formation of the Jatobá Basin (former basal section of the Tacaratu Formation) with the basal section of the Sergipe Basin (Batinga Formation).

Another perspective regarding the lithological similarity between Tacaratu Formation and other Palaeozoic units of the Interior Basins of Northeast Brazil is the detrital composition. As demonstrated in this work, the detrital and mineralogical compositions of the sandstones and conglomerates corresponds to a Stable Craton provenance (Dickinson and Suczek, 1979; Dickinson et al., 1983; Dickinson, 1985), with lowintensity tectonic events on the border of the basin (Fig. 16). Thus, detrital and mineralogical composition is quite the same as for other Palaeozoic units of the Interior Basins. An analogous detrital and provenance composition is verified in other Interior Basins, as evidenced by the Cariri Formation in the Araripe Basin (Batista, 2010; Batista et al., 2012) and Fátima Basin (Menezes-Filho et al., 2013a; b). This fact reinforces the suggested correlation among these basins in the Early to Middle Palaeozoic (Ordovician to Silurian).

The similarity in the palaeocurrent patterns of these Palaeozoic units fits with the palaeogeographic reconstruction proposed by Assine (1994), implying a palaeodrainage flowing to the northwest from the limits of the São Francisco Craton in the state of Bahia to the western limits of the Parnaíba basin in the state of Maranhão (Fig. 17).

\section{Acknowledgements}

We would like to thank LAGESE-GEO-UFPE (Laboratory of Sedimentary Geology of the Department of Geology of Federal University of Pernambuco) for providing the field equipment and laboratory support. This research was partially funded by CNPq (556221/ 2008-7) and FINEP (Projeto Rede 07 - Campos Maduros). Thanks to CNPq for the grants to R. Carvalho, V. Neumann and M. Assine. Thanks also to the reviewers of this paper.

\section{References}

Adams, A.E., Mackenzie, W.S., Guilford, C., 1993. Atlas of Sedimentary Rocks under the Microscope. Harlow Longman, Essex 104 p.

Aragão, M.A., Peraro, A.A., 1994. Elementos Estruturais Do Rifte Tucano/Jatobá. $3^{\circ}$ Simp. Cretáceo Do Brasil. UNESP, Rio Claro, pp. 161-164.

Arai, M., 2006. Revisão estratigráfica do cretáceo inferior das bacias interiores do nordeste do Brasil. Geociências 25 (1), 7-15 São Paulo, UNESP.

Assine, M.L., 1992. Análise estratigráfica da Bacia do Araripe, Nordeste do Brasil. Rev. Bras. Geociencias 22 (3), 289-300.

Assine, M.L., 1994. Paleocorrentes e paleogeografia na Bacia do Araripe, nordeste do Brasil. Rev. Bras. Geociencias 24 (4), 223-232.

Assine, M.L., 2007. Bacia do Araripe. Bol. Geociencias Petrobras 15 (2), 371389.

Barbosa, O., 1964. Geologia de parte da região do médio São Francisco, nordeste do Brasil
PROSPEC/SUDENE, Petrópolis 68p.

Barreto, P.M.C., 1968. O Paleozóico da Bacia do Jatobá, Pernambuco. Boletim da Sociedade Brasileira de Geologia. São Paulo 17 (1), 29-45.

Batista, Z.V., 2010. Estudos de Proveniência e Eventos Diagenéticos da Formação Mauriti, Bacia do Araripe. Dissertação de Mestrado Universidade Federal de Pernambuco, Recife, pp. 134.

Batista, Z.V., Valença, L.M.M., Silva, S. M. A. Da, Neumann, V.H., Santos, C.A., Fambrini, G.L., 2012. Análise de Fácies da Formação Cariri, Bacia do Araripe, Nordeste do Brasil. Estudos Geológicos 22, 03-20.

Brasil, Departamento Nacional de Produção Mineral, 1984. LÉXICO Estratigráfico Do Brasil. (Coord. Milton Brand Baptista, Oscar Paulo Gross Braun. Diógenes Almeida Campos, Brasília 541p.

Braun, O.P.G., 1966. Estratigrafia dos sedimentos da parte interior da região Nordeste do Brasil (bacias de Tucano-Jatobá, Mirandiba e Araripe). DNPM, R.J., Boletim n 236, $75 \mathrm{p}$.

Brito Neves, B.B., 1995. Crátons e Faixas Móveis. Boletim IG-USP. Série Didática 7, 187.

Brito Neves, B.B., Santos, E.J., Van Schmus, W.R., 2000. Tectonic history of the Borborema Province northeastern Brazil. In: In: Cordani, U.G., Milani, E.J., ThomazFilho, A., Campos, D.A. (Eds.), Tectonic Evolution of South America, vol. 31. International Geological Congress, pp. 151182

Caixeta, J.M., Bueno, G.V., Magnavita, L.P., Feijó, F.J., 1994. Bacias de Recôncavo, Tucano e Jatobá. Bol. Geociencias Petrobras 8 (1), 163-172.

Cant, D.J., Walker, R.G., 1978. Fluvial process and facies sequences in the sandy braided South Saskatchewan River, Canada. Sedimentology 25 (5), 625-648.

Caputo, M.V., Crowell, J.C., 1985. Migration of glacial centers across gondwana during paleozoic Era. Bull. Geol. Soc. Am. 96, 1020-1036.

Cesero, P., Ponte, F.C., 1997. Análise comparativa da paleogeologia dos litorais atlânticos brasileiro e africano. B. Geoci. PETROBRAS, Rio de Janeiro 11 (1/2), 1-18.

Costa, I.P., Bueno, G.V., Milhamem, P.S., Carvalho, M.S.S., 2003. Bacias sedimentares brasileiras: bacia do Jatobá. Aracaju: fundação phoenix. Série Bacias Sedimentares 53.

Costa, I.P., Bueno, G.V., Milhamem, P.S., Lima e Silva, H.S.R., Kosin, M.D., 2007. Subbacia Tucano Norte e Bacia do Jatobá. Bol. Geociencias Petrobras 15 (2), 445453.

De Ros, L.F., 1998. Heterogeneous generation and evolution of diagenetic quartzarenites in the siluro-devonian furnas Formation of the parana basin, southern Brazil. Sediment. Geol. 116, 99-128.

De Ros, L.F., 1985. Petrologia e características de reservatório da Formação Sergi (Jurássico) no campo de sesmaria, Bacia do Recôncavo, Brasil. Dissertação de Mestrado. UFOP, Ouro Preto, pp. 101p.

De Ros, L.F., Morad, S., Paim, P.S.G., 1994. The role of detrital composition on the diagenetic evolution of continental molasses: evidences from the Cambro-Ordovician Guaritas Sequence, southern Brazil. Sediment. Geol. 92, 197-228.

De Ros, L.F., Moraes, M.A.S., 1984. Sequência diagenética em arenitos: uma discussão inicial. In: Congresso Brasileiro de Geologia, 33, Rio de Janeiro. Anais, vol. 2. SBG, Rio de Janeiro, pp. 894-901.

Dickinson, W.R., 1988. Provenance and sediment dispersal in relation to paleotectonics and paleogeography of sedimentary basins. In: Kleinspehn, K.L., Paola, C. (Eds.), New Perspectives in Basin Analysis, pp. 3-25.

Dickinson, W.R., 1985. Interpreting provenance relations from detrital modes of sandstones. In: In: Zuffa, G.G. (Ed.), Provenance of Arenites. The Netherlands, NATO-ASI Series C. D, vol. 148. Reidel Pub. Co., Dordrecht, pp. 333-361.

Dickinson, W.R., Suczek, C.A., 1979. Plate tectonics and sandstone compositions. AAPG (Am. Assoc. Pet. Geol.) Bull. 63, 2164-2182.

Dickinson, W.R., Beard, I.S., Brakenridge, G.R., Erjavec, J.L., Ferguson, R.C., Inman, K.F., Knepp, R.A., Lindber, F.A., Ryberg, P.T., 1983. Provenance of North American Phanerozoic sandstones in relation to tectonic setting. Geol. Soc. Am. Bull. 93, 222-235.

Fambrini, G.L., Batista, Z.V., Neumann, V.H.M.L., Valenca, L.M.M., Agostinho, S.M., Menezes Filho, J.A.B., 2013. Sedimentary facies analysis of Cariri Formation, sineclysis stage, Araripe Basin, Northeast Brazil. 6th Latin American Congress of Sedimentology (6lacs), 2013, São Paulo SP. Abstracts, 2013. Single volume.

Folk, R.L., 1968. Petrology of Sedimentary Rocks. The Univ. of Texas, Austin, Hemphil's, pp. 172p.

Ghignone, J.I., 1972. Ensaio de paleogeografia do Nordeste e as sequências sedimentares. In: Congresso Brasileiro de Geologia, 26. Belém, vol. 3. Anais Sociedade Brasileira de Geologia, pp. 21-28.

Ghignone, J.I., 1979. Geologia dos sedimentos fanerozoicos do Estado da Bahia. In: In: Inda, H.A.V. (Ed.), Geologia e recursos minerais do Estado da Bahia: textos básicos, Salvador, vol. 1. pp. 24-117.

Gomes, H.A., 2001. Geologia e Recursos Minerais do Estado de Pernambuco. 1, vol. 1. CPRM/GOV, Recife, pp. 198 PE, 2001.

Guzmán-González, J., Fambrini, G.L., Usma, C.C., Oliveira, E.V., 2015. Estratigrafia da Bacia de Jatobá: estado da Arte. Estudos Geológicos, (UFPE) 25, 53-76.

Krynine, P.D., 1940. Petrology and genesis of the third bradford sand. Pennsylvania State College Bulletin 29 134p.

Mabesoone, J.M., 1977. Paleozoic-Mesozoic deposits of the Piauí-Maranháo Syneclise (Brazil): geological history of a sedimentary basin. Sediment. Geol. 19, 7-38.

Mabesoone, J.M., 1994. Sedimentary Basins of Northeast Brazil, first ed. Editora Universitária - Universidade Federal de Pernambuco, Recife, pp. 308.

McBride, E.F., 1989. Quartz cementation in sandstones - a review. Earth Sci. Rev. 26, 69112.

Magnavita, L.P., 1994. Deformation Mechanisms in Porous Sandstones of the RecôncavoTucano-jatobá Rift: Implications in the Development of Fault Seal. $3^{\circ}$ Simp. Cretáceo Do Brasil. UNESP, Rio Claro, pp. 173-174.

Magnavita, L.P., Cupertino, J.A., 1987. Concepção atual sobre as bacias de Tucano e Jatobá, Nordeste do Brasil. Bol. Geociencias Petrobras 1 (2), 119-134. 
Magnavita, L.P., Destro, N., Carvalho, M.S.S., Milhomem, P.S., Souza-Lima, W., 2003. Bacias Sedimentares Brasileiras: Bacia de Tucano. Aracaju: Fundação Paleontológica Phoenix, vol. 52 Série Bacia Sedimentares.

Menezes-Filho, N.R., Santos, R.A., Souza, J.D., 1988. Programas Levantamentos Geológicos Básicos Do Brasil: Santa Brígida - Folha SC 24-x-c-v. Companhia de Pesquisa e Recursos Minerais, Brasília, pp. 113p.

Menezes-Filho, J.A.B., Bomtempo Filho, E.B., Durval, L.G.O., Fambrini, G.L., Valenca, L.M.M., Neumann, V.H.M.L., Chaves, O.L., 2013a. Análise faciológica da sucessão sedimentar fluvial da Formação Tacaratu, Bacia de Fátima, Nordeste do Brasil. In: 6th Latin American Congress of Sedimentology (6lacs), 2013, São Paulo SP, Abstracts. 2013. v.único.

Menezes-Filho, J.A.B., Fambrini, G.L., Neumann, V.H.M.L., Bomtempo Filho, E.B., Durval, L.G.O., Chaves, O.L., 2013b. Fácies fluviais identificadas na Formação Tacaratu, Bacia de Fátima, NE do Brasil. In: XXV Simpósio de Geologia do Nordeste, 2013, Gravatá PE. Conferências e Resumos Boletim 23. v.único, pp. 193-194.

Miall, A.D., 2000. Principles of Sedimentary basin Analysis, $3^{\text {trd. }}$ ed. Springer-Verlag, New York, pp. 616.

Miall, A.D., 1996. The Geology of Fluvial Deposits: Sedimentary Facies, basin Analysis and Petroleum Geology. Springer, Berlin 582 p.

Miall, A.D., 1978. Lithofacies types and vertical profile models in braided-rivers deposits: a summary. In: Miall, A.D. (Ed.), Fluvial Sedimentology. Calgary, Canadian Society of Petroleum Geologists. Canadian Society of Petroleum Geologists Memoir n. 5), pp. 597-604.

Morad, S., Ketzer, J.M., De Ros, L.F., 2000. Spatial and temporal distribution of diagenetic alterations in siliciclastic rocks: implications for mass transfer in sedimentary basins. Sedimentology 47 (1), 95-120.

Moraes Rego, L.F., 1936. O Valle do São Francisco. Ensaio de Monographia Geographica, vol. 20. Separata da Revista do Museu Paulista da USP, pp. 491-706.

Neumann, V.H., 2017. Geologia e recursos minerais da Folha Poço da Cruz, SC.24-X-A-VI Estados de Pernambuco e de Alagoas: texto explicativo. CPRM - Serviço Geológico do
Brasil, Brasília 2017. 61p. il. 1 mapa geológico, escala 1:100.000.

Neumann, V.H., Rocha, D.E.G.A., Moraes, A.S., Sial, A.N., Taboada-Castro, M.T., Barbosa, J.A., Fambrini, G.L., Carvalho, R.R., 2010. Microfácies carbonáticas e comportamento isotópico de C e O nos calcários laminados aptianos lacustres da Serra Negra, Bacia do Jatobá, Nordeste do Brasil. Estudos Geológicos 20 (1), 89-100.

Ponte, F.C., 1992. Origem e evolução das pequenas bacias cretácicas do interior do Nordeste do Brasil. In: UNESP/IGCE, Simpósio sobre Bacias Cretácicas Brasileiras, 2. Resumos Expandidos, Rio Claro, pp. 55-58 1992.

Ponte, F.C., Appi, C.J., 1990. Proposta de revisão da coluna estratigráfica da Bacia do Araripe. In: Congresso Brasileiro de Geologia, 36. Sociedade Brasileira de Geologia, Natal, pp. 211-226.

Regali, M.S.P., 1964. Resultados palinológicos de amostras paleozoicas da Bacia de Tucano-Jatobá (seção paleozoica do poço IMST-1-PE), vol. 7. Boletim Técnico da Petrobras, Rio de Janeiro, pp. 165-180 2.

Rocha, D.E.G.A., Amaral, C.A., 2007. Caracterização Geologica e Geométrica dos Aquiferos (Meta B). In: Costa, W. D and Feitosa, F. A. C (Coordenadores). Hidrogeologia da Bacia Sedimentar do Jatobá: Sistema Aqüífero Tacaratu/Inajá. Ministério de Minas e Energia - Ministério da Ciênica e Tecnologia.

Rocha, D.E.G.A., Leite, J.F., 1999. Estudo hidrogeológico da Bacia do Jatobá- PE. Geologia. Série Hidrogeologia - Estudos e Projetos - 2, 20p ilustrado.

Santos, C.F., Cupertino, J.A., Braga, J.A.E., 1990. Síntese sobre a geologia das bacias do Recôncavo, Tucano e Jatobá. In: Raja Gabaglia, G.P., Milani, E.J. (Eds.), Origem e evolução de Bacias Sedimentares. Petrobras, Rio de Janeiro, pp. 235-266.

Scholle, P.A. (Ed.), 1979. A Color Illustrated Guide to Constituents, Textures, Cements, and Porosity of Sandstones and Associated Rocks, vol. 28. American Association of Petroleum Geologists Memoir, Tulsa, Oklahoma, pp. 202.

Souza-Lima, W., Borba, C., Rancan, C.C., Cangussu, L.P., Costa, M.N.C., Menezes, M.R.F., Ribas, N., Galm, P.C., Silva, B.O., Bezerra, P.V., 2011. Formação Karapotó - Uma Nova Unidade Estratigráfica de Provável idade Siluro-Devoniana da Bacia SergipeAlagoas. In: Simpósio de Geologia do Nordeste, 24. Aracaju: Anais, pp. 284. 